\title{
Consciousness-raising, Error Correction and Proofreading
}

\author{
Josephine O’Brien ${ }^{1}$
}

\begin{abstract}
The paper discusses the impact of developing a consciousness-raising approach in error correction at the sentence level to improve students' proofreading ability. Learners of English in a foreign language environment often rely on translation as a composing tool and while this may act as a scaffold and provide some support, it frequently leads to predictable and persistent errors. Such fossilization can cause inaccuracies that detract from student composition and that require instruction and repeated practice in order to eradicate the errors. The current paper reports on an experiment in consciousness-raising about specific categories of errors with a group of 30 students in the Faculty of Education in Zayed University, Dubai during the spring semester 2014. Post-test results compared with those on a pre-test indicate a significant improvement in students' performance as a result of structured input (specially prepared grammar materials) and focused instruction (teaching that focuses on each specific grammar point identified as problematic).
\end{abstract}

Keywords: consciousness-raising, error analysis, structured input, focused instruction

\section{Introduction}

Writing, according to Coulmas (2003) is "the single most consequential technology ever invented" (p. 1) as it provides not only a tool for "reclaiming the past" but also the critical skills necessary for reclaiming the future. While this definition may be a distant dream for EFL students in particular, highlighting the essential nature of writing in the success of any university student is vital. Today, globalization of English, as the language of business, science, technology, travel and medicine, obliges many non-native English speaking students to pursue their academic studies through English. Academic writing even in one's first language (L1) is a complex task as is learning to write effectively in a second language (L2) (Hinkel, 2004) and requires clear guidance at each step of the process. The teaching of writing over the past couple of decades has concentrated on the writing process (Raimes, 1985; Hamlin, 2011) with lessons on how to develop a sophisticated product that reflects clear topic understanding, logical coherence, selective use of academic vocabulary, stylish syntax, grammatical accuracy and avoidance of plagiarism. The final stage in such a process is the proofreading phase in which the writer tries to ensure accuracy of grammar, spelling, and punctuation. While this section of the process may be the least favorite of students, it is essential as outlined by Hacker (2002), "Although proofreading may be dull, it is crucial. Errors strewn throughout an essay are distracting and annoying. If the writer doesn't care about this piece of writing, thinks the reader, why should I? A carefully proofread essay, however, sends a positive message: it shows that you value your writing and respect your readers." (p. 45). The challenge is one of raising students' awareness of their errors, the source of such errors and equipping them with the knowledge to correct these in order to become efficient proof-readers and successful academic writers (Debboune \& Tebib, 2010).

The current research considers how to improve students' ability to proofread their own written work, emerging from the premise that students are not always able to recognize errors when asked to proofread, and feedback in the form of traditional symbols or red marks are not effective unless students are helped to understand the source of persistent errors. In an EFL

${ }^{1}$ Zayed University, Dubai, UAE 
environment, as we find ourselves at Zayed University, students communicate socially through the medium of Emirati Arabic and their first language of literacy is classical Arabic. Therefore, L1 transfer along with developmental features arising from the nature of English have to be considered as influencing factors in the inaccuracies that occur in student writing and remedied by providing structured input and focused instruction.

\section{Literature Review}

Editing and proofreading are often grouped together in teaching the writing process and correction but are two different activities; editing involves reviewing content, organization, style and tone while proofreading requires a "slow methodical search" (Hacker, 2002) for mistakes and errors in grammar, word form, spellings and punctuation that interfere with the production of an error-free copy of one's work (Debboune \& Tebib, 2010; Pagel \& Nostrom, 2010;). While students have grammar resources and advice at hand, both in the person of the teacher and materials, some errors result from deep-seated fossilization and require reinforcement that should be addressed in a very specific manner.

Over-focus on accuracy in the initial composition phase can result in hesitation and anxiety on the part of students and failure to engage effectively with the task in hand. However, inability to carry out effective proofreading will result in a product that, while displaying an ability to engage with questions or topics, is likely to contain errors and mistakes that distract readers and result in grades lower than students could have achieved. For students, the important practical factor in learning to proofread is to improve the grade outcome while at the same time acquiring the incremental benefits of enhancing the writing quality and improving fluency and clarity (Ellis, 1994; 2002). Teachers and students must be the motivators in encouraging and developing the ability to proofread to improve text accuracy and thus ease of reading for audiences. Students who can effectively demonstrate their ability to proofread through focusing on form in context demonstrate literacy competency (Fry 2002; Grenville, 2001; Lightbown \& Spada, 1999) and improve their credibility as students and writers (Galko, 2001).

Students, however, when asked to proofread their work need to be aware of what they should focus on. Learning grammar rules has no value if students are unable to apply these to their work. Cook $(2013,23)$ points out that "Sheer knowledge of language has little point if speakers cannot use it appropriately for all the activities in which they want to take part." Literature on language learning and teaching differentiates between mistakes and errors. Mistakes (Ellis, 1994; 2002) result when students fail to perform competently, a failure that may result from tiredness, inattention or carelessness. In such situations, when attention is drawn to the mistake, students are able to correct it without any further support. Errors, however, are quite different as these are systematic and cannot be rectified unless students are guided and provided with clear explanations that focus on reasons for the error. Several definitions of errors have been proposed and all revolve around Corder's (1967) initial analysis of an error as an inability to use the language system correctly, or as deviations from target language norms (Ellis, 1994). Errors, however, can have a constructive role in the learning process and Umale (2011) argues that an error is "the device that the learner uses in order to learn. It is a way of testing his hypothesis about the nature of language he is trying to learn" (p. 90) and thus reflects the student's underlying functional knowledge to date of the target language grammar. To correct misconceptions, omissions, unnecessary additions and misrepresentations, students need the proper comprehensible structured input and support to develop the skill of noticing to readjust the initial incorrect hypothesis. Several researchers (Celce-Murcia, 2001; Ellis, 2002; Hinkel \& Fotos, 2002; Khodabandeh, 2007) stress the

Journal of the Scholarship of Teaching and Learning, Vol. 15, No. 3, June, 2015. 
importance of raising student awareness of grammatical errors that recur in addition to inbuilding these into syllabus design where they can provide valuable insight.

Initial work on error correction was influenced by the behaviourist theory of learning according to which most errors were classed as mother tongue (L1) interference and were subjected to intense exposure to the correct form through drilling and repetition to rectify the error (James, 1969). However, under the influence of cognitivists and constructivists (Gass et al, 2013; Lightbown \& Spada, 2006; Selinker, 1972; Vygotsky, 1978), a much more active approach was adopted towards error analysis. Learners are now viewed as using their cognitive skills to analyse the target language (L2), recognizing patterns and forming rules based on these patterns. Errors are part of the developmental process and dealing with them is a much more complex process than behaviourist stimulus and response approaches. The cognitivist approach to error analysis and correction involves consciousness-raising (C-R), awareness of error source and adopting an active approach to error correction (Rutherford \& Sharwood-Smith, 1985; Schmidt, 1990).

Through C-R, as defined by Sharwood-Smith (1981), the student's attention is drawn to "structural regularities" so as to develop awareness of patterns and systems in the language, thus ensuring that "the learner is being made conscious of some aspect of the language itself" (p. 160-162). The manner in which this is done varies as Sharwood-Smith points out. Van Patten (1996) referred to structured input as part of the instruction process in an attempt to "alter the processing strategies that learners take to the task of comprehension and to encourage them to make better form-meaning connections than they would if left to their own devices." (p. 296). Suzuki (2007) refers to the value of C-R as offering the learners "ownership of the language, responsibility for the learning process, autonomy of learning and empowerment." (p.23)

While error analysis and correction are now viewed as cognitive with students actively engaged in the learning process, it is acknowledged that students may base their assumptions of the structure of the language on those of the L1 especially in a non-immersion situation, thus forming incorrect hypotheses about the nature of the L2 (Kharma, 1981; Kharma \& Hajjaj, 1997; O’Brien, 2011). Foss and Waters (2007) advise students "when you notice errors that you make frequently, write them down alphabetically on a sheet of paper to create your own personal style sheet. Using this style sheet, you can easily look for the errors you make most frequently.” (p. 2). While this is good advice, the question still revolves around students' ability to notice, categorize and correct errors. In language learning situations as represented by the current research, students may require structured input to help with remedying a persistent error. Drawing attention to errors is only one part of the process of which developing the ability to provide the correct form is surely the next step. One needs also to consider why the error occurs, and this involves a psycholinguistic analysis to help with C-R and to ensure error correction. The major part of the process involved in training students to error correct is to uncover why certain errors recur endlessly. Thus, a systematic analysis of students' work is necessary to identify errors and establish ways of providing constructive feedback and teaching to ensure that students understand the error source and develop the ability to self-correct.

\section{Hypotheses}

Two closely related hypotheses inform the current research.

1. Grammatical competence is likely to improve significantly when students are given structured input on the source and remediation of specific errors. 
2. Grammatical competence is likely to improve significantly when students are involved in peer teaching of identified errors and their ability to notice is improved.

The null hypothesis states that there is likely to be no difference between students' accuracy on a grammar pre-test and post-test after structured input and focused instruction on the identified errors.

To facilitate the exploration of these hypotheses, a pre-test (Appendix A) was designed, and administered at the beginning of the teaching semester and administered again as a posttest during the final week of teaching semester after instruction on the source and remediation of the identified errors. This allows comparison of the effect of structured input and focused instruction on student accuracy in specific grammar categories.

\section{Rationale}

One stated objective of the course in which students were enrolled was to develop grammatical accuracy while at the same time meeting the requirements of their college course. The students are currently studying for an Education degree and many will become English language teachers in primary schools in the UAE. Throughout the course, students were expected to produce reports, review reading materials and complete a variety of writing tasks. The course is designed around education-related content and includes task types expected of an education major. The goal is for students to produce error free work. The current research illustrates one of the course activities developed to facilitate C-R of error analysis with the objective of improving writing accuracy and thus meeting the goals of the course.

\section{Participants}

The participants were 30 students in the Faculty of Education in Zayed University in the UAE. All were female and the majority training to be teachers of English in primary schools in the UAE. All study through the medium of English and some will teach in English medium schools on graduating. All students had attended Arabic medium school before joining the English medium government university. To gain entrance, students take a Common English Proficiency Assessment (CEPA) and based on the outcome of this exam, they are placed in one of the three third level government institutions in the country. Some join Zayed University's Academic Bridge Program where they study English until they achieve an IELTS score of 5.5 (general English user) after which they take three academic reading and writing courses. Students then select their majors and generally do not have any more specific language courses. However in 2013, the university administration decided to create English for the Professions designed specifically to provide language courses in discipline specific colleges, a type of CLIL (Content Language Integrated Learning) approach with the focus very much on writing accuracy. The content of material presented throughout the course in reading, writing and discussion was related to education and where possible to education in the UAE. It was found, however, in the diagnostic writing completed at the beginning of the course that while many of the students had developed as quite sophisticated thinkers and potential education practitioners, student writing still contained many basic errors. The pre-test included seven of these error categories (see below) and a C-R approach was adopted and incorporated into the course to help students. A post-test measured students’ performance after instruction and structured input.

Journal of the Scholarship of Teaching and Learning, Vol. 15, No. 3, June, 2015. 


\section{Research Design}

This study is a quantitative statistical analysis of the effect of developing noticing of grammatical errors committed in seven specific categories and dealt with through peer instruction and specifically designed materials to address perceived error source. The purpose is to analyse the differences between student performance on a pre-test and post-test on the seven grammatical categories (dependent variables) identified as problematic for Arabic speaking students of English. Changes in performance between the pre-test and post-test indicate whether or not the independent variables (teaching approach and specifically designed materials) affect student post-test scores.

\section{Test instrument}

A grammar test was designed, consisting of thirty-four sentences that reflected seven error categories noticed as common in Zayed University student writing and identified as problematic for Arabic L1 students of L2 English (Kharma \& Hajjaj, 1997; O’Brien, 2011). This comprised the research test instrument; the categories are listed below followed by the item (sentence) number in which each error is tested.

- Category 1: Indefiniteness and definiteness: items 1,3,4,10,32,

- Category 2: Omitting verb 'to be': items 5,8,11,14

- Category 3: Referencing: items 7,12,15,16,18,20,21,23,24,28, 29,33,

- Category 4: Subject verb agreement: items 13,17, 22, 31,

- Category 5: Verb tense and aspect: items 9,19,25,26,30,34,

- Category 6: Passive: item 27,

- Category 7: Use of Apostrophe: items 2,6

The pre-test was administered in the second week of the 2014 Spring Semester under test conditions. The students were given 45 minutes to complete the test. Students were instructed to find and correct the error in each sentence on the test sheet. No further indication was given of the type of error to be corrected. The worksheets were collected at the end of the session and though answers were marked and recorded, no feedback was given to the students. Students were given one mark for each error successfully identified and corrected. A mark was not given if students only underlined the error.

\section{Instructional procedure}

The instructional procedure was characterized by the following steps. Throughout the semester, testing and teaching (independent variables) of the test items were conducted with full student participation. Each week, a worksheet (1st exposure to grammar point) consisting of ten sentences on the selected error to be taught in the following lesson was given to students ten minutes prior to the end of class. This was completed in ten minutes and handed to the teacher who corrected and recorded scores without giving any feedback to students. Two students were assigned to prepare a presentation of about $5-8$ minutes in length with material (prepared by the teacher) focusing on the particular type of error associated with the assigned grammar point. If required, the student presenters were encouraged to seek help from the teacher while preparing the presentation which they presented to other students in the following class ( $2^{\text {nd }}$ exposure to grammar point). After the student presentation, students were given another worksheet (3rd exposure to grammar point) to complete in class; on completion, each student exchanged her worksheet ( $4^{\text {th }}$ exposure to grammar point) with a peer who corrected it. The worksheets were then handed back to students who were able to review and question any

Journal of the Scholarship of Teaching and Learning, Vol. 15, No. 3, June, 2015. 
misunderstandings. Finally, students were able to check their first worksheets, which the teacher returned, with the one completed in class ( $5^{\text {th }}$ exposure); students were able to notice errors, apply explanations and clarify any misconceptions as the teacher made a final summing up of what had been covered. In this way, students were exposed to the grammar point five times through the initial worksheet, listening to their peers' presentation and completing the post presentation task, correcting a colleague's paper and then finally teacher correction and clarification. Students all reported that they found this repetition very useful.

Some errors tested during this process showed L1 influence and it was confirmed in discussions that many students were applying L1 rules to L2 grammar situations. Other errors could be classified as developmental. The approach taken throughout the process was cognitive and constructive with efforts made at helping the students analyse the error, raise awareness of the source of the error and develop strategies for correction. The raising awareness process was student driven while the materials were mainly teacher generated, as general grammar books do not always focus in detail on the points covered in the grammar test. These materials are based on extensive analysis of errors made by Arabic students of L2 English (O'Brien, 2011) and available online on a google site. From these materials, the designated students prepared a lesson focusing on the identified error, thus creating structured input to accommodate error correction and increase awareness. The lessons followed the same procedure every week. Two students explained the grammar point through PowerPoint format and whiteboard using Arabic where relevant. As students are potential teachers, they already have had practice in presenting lessons so there was no reluctance to present to their peers. Each week, students were informed of the grammar point for the following week and allowed to choose with whom they would work. Every student in the class was given the opportunity to participate.

In the final $18^{\text {th }}$ week of the semester, students completed the post-test; this was the same test administered in the pre-test of the second week of the semester. Each item containing an error was assigned one mark and students only gained the mark if they successfully identified and corrected the error as in the pre-test.

\section{Findings}

SPSS statistics program was used to conduct a matched pair test on the results, comparing each student's total score on the pre-test with those of the post-test after intervention through structured input. A t-test was employed to calculate the significance of the level of difference at $95 \%$ between pre-test and post-test scores. Results of students' overall performance as well as on individual categories are presented in the following tables followed by a discussion of results.

Table 1

Comparison of students' total scores on pre-test and post-test

\begin{tabular}{|l|l|l|l|l|l|l|l|}
\hline Dates of tests & Test type & No & Mean & $+/$ - SD & $t$-value & df & $p$-value \\
\hline Feb. $9^{\text {th }} 2014$ & Pre-test & 30 & 9.3000 & 5.67602 & & & \\
\hline June $8^{\text {th }} 2014$ & Post-test & 30 & 19.833 & 5.33746 & -15.429 & 29 & .000 \\
\hline
\end{tabular}

Journal of the Scholarship of Teaching and Learning, Vol. 15, No. 3, June, 2015. 
O'Brien, J.

Table 2

Comparison of students' pre-test and post-test scores on indefiniteness and definiteness

\begin{tabular}{|c|c|c|c|c|c|c|c|}
\hline $\begin{array}{l}\text { Definite/ } \\
\text { indefinite }\end{array}$ & Test type & No & Mean & $+/-\mathrm{SD}$ & t-value & df & p-value \\
\hline \multirow[t]{2}{*}{ Item 3} & Pre-test & 30 & .3333 & .47946 & \multirow[b]{2}{*}{-2.504} & \multirow[b]{2}{*}{29} & \multirow[b]{2}{*}{.018} \\
\hline & Post-test & 30 & .6000 & .49827 & & & \\
\hline \multirow[t]{2}{*}{ Item 10} & Pre-test & 30 & .0000 & .0000 & \multirow[b]{2}{*}{-4.097} & \multirow[b]{2}{*}{29} & \multirow[b]{2}{*}{.000} \\
\hline & Post-test & 30 & .3667 & .49013 & & & \\
\hline \multirow[t]{2}{*}{ Item 1} & Pre-test & 30 & .1000 & .30513 & \multirow[b]{2}{*}{-1.980} & \multirow[b]{2}{*}{29} & \multirow[b]{2}{*}{.057} \\
\hline & Post-test & 30 & .2667 & .44978 & & & \\
\hline \multirow[t]{2}{*}{ Item 4} & Pre-test & 30 & .1000 & .30513 & \multirow{2}{*}{-.571} & \multirow{2}{*}{29} & \multirow{2}{*}{.573} \\
\hline & Post-test & 30 & .1333 & .34575 & & & \\
\hline \multirow[t]{2}{*}{ Item 32} & Pre-test & 30 & .0667 & .25371 & \multirow[b]{2}{*}{-2.693} & \multirow[b]{2}{*}{29} & \multirow[b]{2}{*}{.012} \\
\hline & Post-test & 30 & .2667 & .44978 & & & \\
\hline
\end{tabular}

Table 3

Comparison of students' pre-test and post-test scores on use of verb 'to be'

\begin{tabular}{|c|c|c|c|c|c|c|c|}
\hline Omit 'to be' & Test type & No & Mean & $+/-\mathrm{SD}$ & $t$-value & df & $p$-value \\
\hline Item 5 & Pre-test & 30 & .5667 & .50401 & \multirow{2}{*}{-2.804} & \multirow[b]{2}{*}{29} & \multirow[b]{2}{*}{.009} \\
\hline & Post-test & 30 & .8333 & .37905 & & & \\
\hline Item 8 & Pre-test & 30 & .7333 & .44978 & \multirow{2}{*}{-1.682} & \multirow[b]{2}{*}{29} & \multirow[b]{2}{*}{.103} \\
\hline & Post-test & 30 & .8667 & .34575 & & & \\
\hline \multirow[t]{2}{*}{ Item 11} & Pre-test & 30 & .3667 & .49013 & \multirow{2}{*}{-4.709} & \multirow{2}{*}{29} & \multirow{2}{*}{.000} \\
\hline & Post-test & 30 & .8000 & .40684 & & & \\
\hline \multirow[t]{2}{*}{ Item14 } & Pre-test & 30 & .6000 & .49827 & \multirow{2}{*}{-3.808} & \multirow{2}{*}{29} & \multirow{2}{*}{.001} \\
\hline & Post-test & 30 & .9333 & .25371 & & & \\
\hline
\end{tabular}

Journal of the Scholarship of Teaching and Learning, Vol. 15, No. 3, June, 2015. 
O'Brien, J.

Table 4

Comparison of students' pre-test and post-test scores on referencing

\begin{tabular}{|c|c|c|c|c|c|c|c|}
\hline Reference & Test type & $\mathrm{N}$ & Mean & $+/-\mathrm{SD}$ & $t$-value & $\mathrm{df}$ & $p$-value \\
\hline Item 7 & Pre-test & 30 & .3667 & .49013 & \multirow{2}{*}{-2.262} & \multirow{2}{*}{29} & \multirow{2}{*}{.031} \\
\hline & Post-test & 30 & .5667 & .50401 & & & \\
\hline \multirow[t]{2}{*}{ Item 12} & Pre-test & 30 & .3667 & .49013 & \multirow[b]{2}{*}{-1.989} & \multirow[b]{2}{*}{29} & \multirow[b]{2}{*}{.056} \\
\hline & Post-test & 30 & .5667 & .50401 & & & \\
\hline \multirow[t]{2}{*}{ Item 18} & Pre-test & 30 & .2667 & .44978 & \multirow{2}{*}{-2.249} & \multirow[b]{2}{*}{29} & \multirow[b]{2}{*}{.032} \\
\hline & Post-test & 30 & .5000 & .50855 & & & \\
\hline \multirow[t]{2}{*}{ Item 16} & Pre-test & 30 & .1333 & .34575 & \multirow[b]{2}{*}{-3.247} & \multirow[b]{2}{*}{29} & \multirow[b]{2}{*}{.003} \\
\hline & Post-test & 30 & .4000 & .49827 & & & \\
\hline \multirow[t]{2}{*}{ Item 23} & Pre-test & 30 & .3667 & .49013 & \multirow{2}{*}{-2.536} & \multirow{2}{*}{29} & \multirow{2}{*}{.017} \\
\hline & Post-test & 30 & .6000 & .49827 & & & \\
\hline \multirow[t]{2}{*}{ Item 33} & Pre-test & 30 & .2667 & .44978 & \multirow[b]{2}{*}{-3.010} & \multirow[b]{2}{*}{29} & \multirow[b]{2}{*}{.005} \\
\hline & Post-test & 30 & .6000 & .49827 & & & \\
\hline \multirow[t]{2}{*}{ Item 15} & Pre-test & 30 & .2667 & .44978 & \multirow[b]{2}{*}{-2.504} & \multirow[b]{2}{*}{29} & \multirow[b]{2}{*}{.018} \\
\hline & Post-test & 30 & .5333 & .50742 & & & \\
\hline \multirow[t]{2}{*}{ Item 29} & Pre-test & 30 & .30513 & .47946 & \multirow[b]{2}{*}{-3.890} & \multirow[b]{2}{*}{29} & \multirow[b]{2}{*}{.001} \\
\hline & Post-test & 30 & .50855 & .44978 & & & \\
\hline \multirow[t]{2}{*}{ Item 28} & Pre-test & 30 & .6333 & .49013 & \multirow{2}{*}{-2.804} & & \\
\hline & Post-test & 30 & .9000 & .30513 & & 29 & .009 \\
\hline Item 20 & Pre-test & 30 & .1667 & .37905 & & & \\
\hline & Post-test & 30 & .6333 & .49013 & -4.474 & 29 & .000 \\
\hline Item 21 & Pre-test & 30 & .0667 & .25371 & & & \\
\hline & Post-test & 30 & .3667 & .49013 & -3.525 & 29 & .001 \\
\hline Item 24 & Pre-test & 30 & .3667 & .49013 & & & \\
\hline & Post-test & 30 & .8667 & .34575 & -4.785 & 29 & .000 \\
\hline
\end{tabular}

Journal of the Scholarship of Teaching and Learning, Vol. 15, No. 3, June, 2015. 
O'Brien, J.

Table 5

Comparison of students' pre-test and post-test scores on subject-verb agreement

\begin{tabular}{|l|l|l|l|l|l|l|l|}
\hline Subject/verb & Test type & $\mathrm{N}$ & Mean & + +- SD & t-value & df & p-value \\
\hline Item 13 & Pre-test & 30 & .4333 & .50401 & & & \\
& Post-test & 30 & .7667 & .4308 & -3.340 & 29 & .002 \\
\hline Item 17 & Pre-test & 30 & .1333 & .34575 & & & \\
\hline & Post-test & 30 & .5000 & .50855 & -3.612 & 29 & .001 \\
\hline Item 22 & Pre-test & 30 & .5000 & .50855 & & & \\
\hline & Post-test & 30 & .7333 & .44978 & -2.971 & 29 & .006 \\
\hline
\end{tabular}

Table 6

Comparison of students' pre-test and post-test scores on verb tense and aspect

\begin{tabular}{|c|c|c|c|c|c|c|c|}
\hline Tense \& aspect & Test type & $\mathrm{N}$ & Mean & $+/-\mathrm{SD}$ & $t$-value & $\mathrm{df}$ & $p$-value \\
\hline Item 9 & Pre-test & 30 & .2000 & .40684 & \multirow{2}{*}{-3.071} & \multirow{2}{*}{29} & \multirow{2}{*}{.005} \\
\hline & Post-test & 30 & .5000 & .50855 & & & \\
\hline \multirow[t]{2}{*}{ Item 25} & Pre-test & 30 & .1000 & .30513 & \multirow[b]{2}{*}{-3.071} & \multirow[b]{2}{*}{29} & \multirow[b]{2}{*}{.005} \\
\hline & Post-test & 30 & .4000 & .49827 & & & \\
\hline \multirow[t]{2}{*}{ Item 19} & Pre-test & 30 & .3333 & .47946 & \multirow[b]{2}{*}{-3.980} & \multirow[b]{2}{*}{29} & \multirow[b]{2}{*}{.001} \\
\hline & Post-test & 30 & .7333 & .44978 & & & \\
\hline \multirow[t]{2}{*}{ Item 26} & Pre-test & 30 & .1667 & .37905 & \multirow[b]{2}{*}{-5.037} & \multirow[b]{2}{*}{29} & \multirow[b]{2}{*}{.000} \\
\hline & Post-test & 30 & .6333 & .49013 & & & \\
\hline \multirow[t]{2}{*}{ Item 30} & Pre-test & 30 & .0000 & .00000 & \multirow{2}{*}{-2.112} & \multirow[b]{2}{*}{29} & \multirow{2}{*}{.043} \\
\hline & Post-test & 30 & .1333 & .34575 & & & \\
\hline \multirow[t]{2}{*}{ Item 31} & Pre-test & 30 & .4333 & .50401 & \multirow{2}{*}{-3.266} & \multirow{2}{*}{29} & \multirow{2}{*}{.003} \\
\hline & Post-test & 30 & .8000 & .40684 & & & \\
\hline \multirow[t]{2}{*}{ Item 34} & Pre-test & 30 & .2000 & .40684 & \multirow{2}{*}{-3.340} & \multirow{2}{*}{29} & \multirow{2}{*}{.002} \\
\hline & Post-test & 30 & .5333 & .50742 & & & \\
\hline
\end{tabular}

Journal of the Scholarship of Teaching and Learning, Vol. 15, No. 3, June, 2015. 
O'Brien, J.

Table 7

Comparison of students' pre-test and post-test scores on use of passive

\begin{tabular}{|l|l|l|l|l|l|l|l|}
\hline Passive & Test type & $\mathrm{N}$ & Mean & $+/$-SD & $t$-value & $\mathrm{df}$ & $p$-value \\
\hline Item 27 & Pre-test & 30 & .3333 & .47946 & & & \\
& & & & & -1.720 & 29 & .096 \\
& Post-test & 30 & .5000 & .50855 & & & \\
\hline
\end{tabular}

Table 8

Comparison of students' pre-test and post-test scores on use of apostrophe

\begin{tabular}{|c|c|c|c|c|c|c|c|}
\hline Apostrophe & Test type & $\mathrm{N}$ & Mean & $+/-\mathrm{SD}$ & $t$-value & $\mathrm{df}$ & $p$-value \\
\hline Item 2 & Pre-test & 30 & .3333 & .47946 & \multirow{2}{*}{-2.971} & \multirow[b]{2}{*}{29} & \multirow[b]{2}{*}{.006} \\
\hline & Post-test & 30 & .5667 & .50401 & & & \\
\hline Item 6 & Pre-test & 30 & .1667 & .37905 & \multirow{2}{*}{-2.804} & \multirow{2}{*}{29} & \multirow{2}{*}{.009} \\
\hline & Post-test & 30 & .4333 & .50401 & & & \\
\hline
\end{tabular}

\section{Discussion}

Comparison of overall scores on pre-test and post-test (Figure 1) indicates that there is a highly significant difference between students' performance on a grammar test with a $p$-value of .000. The following discussion considers performance in the seven grammar categories.

\section{Category 1 - Definiteness and indefiniteness (Figure 2).}

Items 1, 3 and 10 examine students' use of the indefinite article 'a/ an' while items 4 and 32 consider use of the definite article 'the'. The concepts of indefiniteness and definiteness exist in English and Arabic; thus student problems are not conceptual but rather inability to deal with restrictions on marking English indefiniteness and definiteness. The Arabic mark of indefiniteness 'tanwin' is a sub/superscript diacritic generally added to Classical Arabic texts and not a free morpheme; it can be placed on singular and plural nouns while the English indefinite article is number sensitive. The main error committed by Arabic speakers with the English indefinite article 'a/an' is its addition on plural nouns or omitting it completely where needed with singular nouns. In the case of definiteness, there are far fewer restrictions on the inclusion of 'al' (Arabic definite article) than there are on the use of 'the' in English, which generally does not occur with abstract nouns and uncountable nouns, thus leading to overuse in English (Kharma \& Hajjaj 1997; O’Brien, 2011).

Items 3 and 10 tested students' ability to correct incorrect use of 'a' with plural nouns, an error type generally not focused on in conventional grammar analyses of the indefinite article. Differences between pretest and posttest scores indicate a significant difference at the $5 \%$ level between students' performance on both tests.

*'Many young people choose a bad role models and that affects their lives. (Item 3)

Journal of the Scholarship of Teaching and Learning, Vol. 15, No. 3, June, 2015. 
*'If we ignore problem related to our identity, it will destroy what makes us a unique individuals.' (Item 10): Item 1 illustrates another common error with definite article usage in English. In nominal sentences with singular subject nouns and a complement consisting of an adjective only, no indefinite article is required as in 'Having a good role model is very important in education.' However, when the complement contains an adjective and a noun, as in the example given in Item 1, 'Having a good role model is an important factor in education.' an indefinite article is required. Scores on the pre and post-test tests indicate no significant difference in students' performance between the two tests.

*'Having a role model is very important factor in a student's life.' (Item 1)

This suggests that more attention needs to be paid to students' inability to notice the adjective noun phrases and modify the omission and misuse of the indefinite article accordingly.

The overuse of the definite article has been noted by Kharma (1981) as the most common error among Arabic writers in English, a point noted also by Farghal \& al Zou'bi (2004). The most common error according to Crompton (2011) is the use of the definite article with generic plural nouns. However, the current research based test items on sentences produced by students in their academic writing and the over-use of 'the' with abstract nouns was found to be the most frequent error as occurs in the two examples given here:

*'The life today makes it necessary for everyone to have a good education in order to succeed.' (Item 4)

*'In India, the education is not the first priority for all children. (Item 32)

While the first example indicates no significant difference between pre- and post- tests, the second result does. Such results illustrate the complexity of dealing with error analysis and correction and I would posit here that the first sentence is a translation of a frequently used expression in Arabic 'al hiya' directly realized in English as 'the life' and very difficult to eradicate a phrase that is reinforced constantly as 'the life' while the second also indicating overuse of 'the' is a less commonly heard expression 'the education' and this item may have improved with development of awareness.

\section{Category 2 - Omitting the verb 'to be' (Figure 3).}

Two main errors result from insufficient understanding of the use of the verb 'to be' in English: omission and overuse. While it is often erroneously noted that Arabic has no verb 'to be', it is true that in Arabic nominal sentences the inclusion of the verb 'to be' 'kana' is not a requirement thus resulting in a verb-less sentence. Translation of nominal sentences from Arabic to English often results in incomplete English sentences such as 'My name Muhammad Ali and I an Emirati'. This is a perfectly acceptable construction in Arabic 'ismii (name my) Muhammad Ali wah (and) ana (I) emiratii'. It is reasonably straightforward to practise the correct form of such sentences with students but in sentences with complex noun phrases and a simple verb 'to be' form, there is a tendency to omit the verb 'to be'. Items 5 and 8 require students to note the absence of the verb 'to be' in:

*'Each generation different from the generation that went before it.' (Item 5)

*'The internet a valuable tool for education and students find it useful.' (Item 8)

Such structures are more complex than the simple nominal example given above and challenge students in proofreading. Results for item 5 show a significant difference between pre- and post-tests while item 8 had an initial score of $74 \%$ on the pre-test increasing to $87 \%$ in the post-test but statistically this did not register as significant.

Items 11 and 14 also tested students' problems with the verb 'to be' in terms of its overuse i.e. using it with another finite verb. It is hypothesized that such usage may result from over compensation or fear of omitting 'to be' where necessary. In translating nominal sentences Journal of the Scholarship of Teaching and Learning, Vol. 15, No. 3, June, 2015. 
from Arabic to English, it has been observed that there is a tendency to translate personal pronouns such as huya 'he' as 'he is' to compensate for the lack of a corresponding verb 'to be' in Arabic in present simple. When the pronoun occurs with a main verb, students may add a redundant 'is' before the main verb as in the following examples.

*'The boys had a very good teacher in primary school. He is gave them a very good education.' (Item 14).

Overuse of the verb 'to be' in item 11 illustrates a further possibility of translation interference as an utterance such as

*'The school we attend, it is affects our future career' (Item 11) would carry the pronoun 'hiya' feminine 'she/it' referring to the feminine noun 'school' and again suggests translation of 'hiya' as 'it is'. Results for both items show a significant difference in pre- and post-tests.

\section{Category 3 - Referencing (Figure 4).}

Another common error found in students' work is the occurrence of redundant pronouns in relative clauses. Three test items illustrate this error.

* 'I did not learn much during the twelve years that I spent it at secondary school.' (Item 7)

*'With technology, everything that we need it will be easy to find it.' (Item 12)

*‘There are many characteristics that every hero should have it.' (Item18)

Such an error is comprehensible from a contrastive perspective as two factors are likely to be influencing production. Inclusion of a pronoun after the verb in such a sentence reflects correct Arabic structure; when the reference noun is inanimate even when plural the Arabic pronoun referring to this noun is singular. Structured input provided students with C-R tasks and resulted in significant differences at the 95\% level in items 7 and 18 while the difference in tests in item 12 was not significant.

A second type of error in referencing is the lack of number correspondence between a referent noun and its pronoun reference. The first example here can be traced to L1 influence as the system in Arabic involves the use of a singular pronoun when referring to plural inanimate nouns:

*'Computers are important tools; it opens doors and saves time and money.' (Item 16) As the word 'computers' is inanimate, the corresponding reference pronoun in Arabic to 'it' would be correct. Results show a significant difference on the posttest.

* 'When children fall behind in schoolwork, parents tend to take him out of school' (Item 23) cannot be traced to Arabic influence as the word 'children' refers to animate beings; therefore the mistake might have to be classed as inattention to the referent in the first half of the sentence. It could be argued that this occurs because of inadequate reading skills. It has been observed that students' reading approach is often word-by-word rather than reading holistically for overall meaning. Significant differences were observed between pre and posttests on this item. Item 33 tests agreement between nouns.

* 'Because children work very hard, their body is weak.' (Item 33)

Here again, it could be argued that there is a failure to consider the number of the noun in the subordinate clause that begins the utterance. It would appear that the concept of grammatical agreement in many forms presents challenges to students as further examples below indicate.

Results between pre- and post-tests indicate significant improvement: Items 15 and 29 involve recognizing the relative pronoun referent as singular or plural and making the choice of verb accordingly. An Arabic relative pronoun is number specific and the relevant verb agrees with this pronoun form. However, in English relative pronouns are not number specific and 
this may be problematic for learners when choosing the corresponding verb form. Results on the post-test show significant difference.

*'Girls should get a good education and that help them to build ....... (Item 15)

*'The condition that lead to child labour is present in many developing countries.' (Item

Subject verb agreement with a plural subject was tested in items 20, 21 and 28. Item 28 is quite straightforward *'Both India and Indonesia has a high incidence of child labour' and results show a significant improvement between pre- and post-tests. Items 20 and 21 contain relative clauses, which present a more challenging option to students as each sentence contains singular and plural nouns and a relative pronoun that can refer to singular and plural nouns.

* 'The second category is the very brave people who shows great courage in their actions.' (Item 20)

* 'She gives the hero some mythological powers that is part of his essential abilities and powers.'

Results on both items show significant improvement. Item 24 tests the use of the demonstrative adjective.

* 'This kinds of jobs are not suitable for young people.'

Students are generally taught that adjectives in English do not agree with the noun e.g. adjectives do not have a plural form except 'this' and 'that', both of which are also demonstrative adjectives. If students have internalized the adjective rule, they are likely to produce the incorrect utterance found in Item 24. Another possible influencing factor is the fact that the equivalent to 'this' and 'that' in Arabic, while having a plural form, does not use the plural form with inanimate plural nouns. The difference between pre- and post-tests is significant. This again indicates that students appear to have benefited greatly from focused instruction although the test contained only one test item on 'this'.

\section{Category 4 - Subject-verb agreement (Figure 5).}

While the grammar of English does not involve learning case endings on nouns, agreement between various aspects of the language are important; in the following items subject verb agreement was tested. Such errors are considered developmental rather than contrastive and can occur among students from a variety of language backgrounds. Aspects of English grammar challenge students to pay attention to detail and to differentiate between specific usages. One of the most common errors among students of all language backgrounds is the failure to recognize the importance of selecting the correct part of the present simple tense verb when referring to singular or plural. Five items tested students' recognition of subject verb agreement with ' $s$ ' in present simple, singular subject and of these, three items $(13,17$, 22) test subject verb agreement in simple sentences:

*'Suitable material helps children learn concepts in a short period of time.' (Item 13)

*'Pollster identifies five important traits of a hero and mention that all may be present in one person. (Item 17)

*'He have to learn from the world around him.' (Item 22)

While all three items show a significant improvement in scores between pre- and posttests, Item 22 is significant at the 0.05 level indicating a lower level of significance than Items 13 and 17.

\section{Category 5 - Verb tense and aspect (Figure 6).}

It has been argued that Arabic is more an aspectual than tense language and thus focuses on the relationship of events to each other, their frequency and duration rather than the Journal of the Scholarship of Teaching and Learning, Vol. 15, No. 3, June, 2015. 
relationship of an event to the speaker's time location at the moment of utterance. While there is concern with tense in Arabic, aspect often takes precedence in choice of verb form. All items in this section illustrate significant difference at .005 level, except item 30 which is still significant at .05 level. Item 9 is a conditional sentence for which rules in English are very clear. Choice of tense indicates modality with a present or future verb form indicating the likelihood of the occurrence of an event. However, the focus on such utterances in Arabic is on the relationship between the two events and in cases of possibility of the event taking place, the verb in the 'if' conditional clause would be in perfective aspectual form usually translated as past tense in English. The logic here is clear as the event in the main clause cannot occur unless the condition in the 'if' clause is realized.

* 'Students will communicate with their friends if they worked in a group.' (Item 9)

Similarly in clauses with 'when', aspectual considerations appear to dictate the choice of past tense in the time clause as in:

* 'When children worked on the farms, heavy machinery causes injury.' (Item 25)

In such an utterance, the focus is on verb and verb harmony so either present tense in both clauses or past would be acceptable as no context is given to clarify the time frame. Results here reflect those of item 25.

Other examples of failure to observe tense harmony on verb forms can be seen in Items 19 and 26. In both these items, the possibility of L1 influence could be argued. The discourse approach to verb form in Arabic is to establish time location in the first verb in the paragraph and it is frequently noted that verbs occur in the imperfective form in the rest of the paragraph. In the two examples given here, the initial verb locates events in past time:

* 'She worked very hard in her company and creates many ideas to develop the company.' (Item 19)

* 'Even where schools were available, the quality of education is often bad.' (Item 26)

With structured input on the importance of verb harmony in English, results showed a significant improvement at .005 on both items.

Two other items 30 and 34 tested students' ability to interpret time and use verbs in the correct form. Item 30 has two verbs together in the introductory phrase while item 34 incorrectly uses the progressive forms (without verb to be) with both verbs.

*'To help solving this problem, the world should cooperate and make a law to protect children.' (Item 30)

*’'We pretending that child labour does not exist and this making us feel better.' (Item

Returning to the argument that Arabic tends to focus on aspect rather than tense would help explain student errors in both these sentences as both situations illustrate on-going events and Arabic speakers frequently identify the -ing form of the verb as indicating the habitual whereas in English the present simple form is used to indicate habits. Results show significance at .05 on item 30 and .005 on item 34. It could be argued that the significantly greater improvement noticed in Item 34 results from a more straightforward use of the verbs as item 30 involves correcting a two-word verb phrase.

\section{Category 6 - Passive (Figure 7).}

The passive is a voice and not tense or aspect; one item in the test checked students' ability to correct the use of English passive. Possible reasons why students find the English passive challenging is that the passive is not used for stylistic purposes in Arabic discourse and is only included when the agent is unknown. Its formation is straightforward in Arabic as it involves only a short vowel change. The formation of the English passive is challenging for 
students and they tend to get confused between past simple, past passive and the verb 'to be' along with some variation on the main verb. Item 27 represents a typical reproduction of a student's understanding or lack of the present passive:

*'Most of the children are forced by their families to work.' (Item 27)

Results show no significant difference between pre- and post-tests suggesting that students have not grasped the structure of the English passive.

\section{Category 7 - Apostrophe (Figure 8).}

The final tested grammatical item included here is the use of the English apostrophe. Usage of the apostrophe presents challenges not just for $\mathrm{L} 2$ language learners but also for native speakers and appears to illustrate inability to differentiate between correct forms.

The following two items tested uses of the apostrophe in contractions and possession.

* 'Knowledge is very important in our lives. Its not limited to our education only.' (Item 2)

* 'Some teachers do not care about a students career and progress.' (Item 6)

Results for both items show significant differences between pre- and post-tests.

\section{Conclusions and Recommendations}

It is clear from the analysis of results that focused teaching with structured input of challenging items yielded positive benefits, as overall post-test results were significantly higher than pre-test results. The null hypothesis is, therefore, rejected. While this was a small group of mature students, results do suggest that analysis of specific problems faced by students in accuracy followed by focused teaching would yield positive outcomes. A generic grammar book provides a general explanation of specific grammar points but does not investigate in detail the challenges that might present themselves to people from a range of L1 backgrounds. It would appear from results that working from materials that have been developed based on analysis of student errors and providing the students with comprehensible structured input and opportunities to understand the specific difficulties through focused instruction would greatly benefit Arabic speakers of English as an L2 in an EFL environment. Therefore, it could be argued that a pedagogical grammar designed to rectify some of the fossilized errors of Arabic speakers of English would be beneficial. More research needs to be conducted in ability to proofread effectively involving a more longitudinal analysis of students' writing in the semesters after the post-test to establish whether or not the remediation conducted through the structured input and focused instruction has in fact been long term.

\section{Appendix}

\section{Pre-test and Post-test}

Name:

\section{Grammar test}

Read the following sentences and decide if they are correct or not. If they are correct put a tick beside each one and if not correct, correct what you feel is wrong over the incorrect form.

1. Having a role model is very important issue.

2. Knowledge is very important in our lives. Its not limited to the educational area.

3. Many young people choose a bad role models and that affects their lives.

4. The life today makes it necessary for everyone to have a good education in order to succeed.

Journal of the Scholarship of Teaching and Learning, Vol. 15, No. 3, June, 2015. 
5. Each generation different from the generation that went before it.

6. Some teachers do not care about a student career and progress.

7. I did not learn much during the twelve years that I spent it at secondary school.

8. The internet a valuable tool for education and students might find it useful.

9. Students will communicate with their friends if they worked in a group.

10. If we ignore problems related to our identity, this will destroy what makes us a unique individuals from the rest of the world.

11. The school we attend is affects our future career.

12. With technology, everything that we need will be easy to find it.

13. Suitable material help children to learn concepts in a short period of time.

14. The boys had a very good teacher in primary school. He is gave them opportunities to be successful in their lives.

15. Girls should get a good education and that help them to build a strong foundation for the family.

16. Computers are important tools; it opens doors and saves time and money.

17. Pollster identifies five important traits of a hero and mention that all of these may not be present in one person.

18. There are many characteristics that every hero should have it.

19. She worked very hard in her company and create so many ideas to develop the company.

20. The second category is the very brave people who shows great courage in their actions.

21. She gives the hero some mythological powers that is part of his essential abilities and powers.

22. He have to learn from the world around him.

23. When children fall behind in school, parents tend to take him out of school.

24. This kinds of jobs are not suitable for young people.

25 . When children worked on the farms, heavy machinery causes injuries.

26. Even where schools were available, the quality of education is often very bad.

27. Most of the children are force by their families to work.

28. Both India and Indonesia has a high rate of child labor.

29. The condition that lead to child labor is present in many developing countries.

30. To help solving this problem, the world should cooperate and make a law to protect children.

31. The government do not work to solve this problem.

32. In India, the education is not the first priority for children.

33. Because children work very hard, their body is weak.

34. We pretending that child labor does not exist and this making us feel better.

\section{References}

Canale, M., \& Swain, M. (1980). Theoretical bases of communicative approaches to second language teaching and testing. Applied Linguistics. 1(1), 1 - 47.

Celce-Murcia, M. (2011) Teaching English as a second or foreign language. Boston: Heinle \& Heinle.

Cook, V. (2013). Second language learning and second language teaching. (4 ${ }^{\text {th }}$ edition). New York: Routledge.

Journal of the Scholarship of Teaching and Learning, Vol. 15, No. 3, June, 2015. 
O'Brien, J.

Corder, S. P (1967). The significance of learners' errors. International Review of Applied Linguistics, 5, 161 - 169.

Coulmas, F. (2003). Writing Systems: An introduction to their linguistic analysis. Cambridge: Cambridge University Press.

Crompton, P. (2011). Article errors in the English writing of advanced L1 Arabic learners: The role of transfer. Asian EFL Journal. 50 (February 11), 4-32.

Debboune, Z., \& Tebib, D. (2010). Notes from the effectiveness of proofreading in minimizing mistakes in students' writing: The case of third year students. Algeria: University of Constantine.

Ellis, R. (1994). The study of second language acquisition. Oxford: Oxford University Press.

Ellis, R. (2002). The place of grammar instruction in the second/foreign language curriculum. In E. Hinkel \& S. Fotos (Eds.), New perspectives on grammar teaching in the second language classroom (pp. 17-34). Mahwah, New Jersey: Lawrence Erlbaum Associates.

Ellis, R (2002). Methodological options in grammar teaching materials. In E. Hinkel \& S. Fotos (Eds.), New perspectives on grammar teaching in second language classrooms (pp.155-179). Mahwah, New Jersey: Lawrence Erlbaum Associates.

Farghal, M., \& al-Zoubi,I. (2004). The Qur'anic definite article in translation: The case of citing animals. In. R. Elhamy, H. Mansour \& J.R. Aydelott (Eds.), Contrastive rhetoric: Issues, insights and pedagogy (pp. 61-68). Cairo: American University Press.

Khodabandeh, F. (2007). Analysis of students' errors: the case of headlines. The Asian ESP Journal, 3(1), $6-15$.

Foss, S.K., \& Waters, W. (2007) Destination dissertation: A traveler's guide to a done dissertation. Maryland: Rowman \& Littlefield.

Fry, R. (2002). Last minute term papers. New Jersey: Career Press.

Galko, F. D. (2001). Better writing right now: Using words to your advantage. New York: Learning Express.

Gass, S. Behney, J., \& Plonsky, L. Second language acquisition: An introductory course. New York: Routledge.

Grenville, K. (2001). Writing from start to finish: A six-step guide. New South Wales: Allen \& Unwin.

Hacker, D. (2002). The Bedford handbook. Boston: Bedford/St. Martin's.

Journal of the Scholarship of Teaching and Learning, Vol. 15, No. 3, June, 2015. 
O’Brien, J.

Hamlin, C. (2011). The writing process: Step-by-step approach curbs plagiarism, helps students build confidence in their writing ability. Faculty Focus. Retrieved 30 May 2014, from http://www.facultyfocus.com/articles/effective-teaching-strategies/the-writing-process step-by-step-approach-curbs-plagiarism-helps-students-build-confidence-in-their-writingabilities/

Heaton, J.B. (1979). Writing English language tests. London: Longman.

Hinkel, E. (2004). Teaching academic ESL writing. Mahwah, New Jersey: Lawrence Erlbaum Associates, Publishers.

Hinkel, E., \& Fotos, S. (2002). New Perspectives on grammar teaching in second language classrooms. Mahwah, N.J.: L. Erlbaum Associates.

James, C. (1969). Deeper contrastive study. International Review of Applied Linguistics, 7 (2), 83-95.

Krashen, S. (1981). Second language acquisition and second language learning. California: Pergamon Press.

Kharma, N. (1981). Analysis of the errors committed by Arab university students in the use of English definite-indefinite articles. International Review of Applied Linguistics, 19(4), 331-345.

Kharma, N., \& Hajjaj, A. (1997). Errors in English among Arabic speakers: Analysis and remedy. Beirut: York Press Librairie du Liban.

O’Brien, J. (2010). Tense and aspect in the interlanguage of Gulf Arab learners. Saarbrucken: Verlag.

O’Brien, J. (2011). Teaching English to Arab learners: A case for a pedagogical grammar. In C. Gitsaki (Ed), Teaching and learning in the Arab World (pp.442-461). Berne: Peter Lang.

Pagel, L.G., \& Nostrom, B. (2010). Proofreading \& editing precision (6 $6^{\text {th }}$ edition, pp. 442-461). Ohio: Cengage Learning.

Lightbown, P.M. \& Spada, N. (2006). How languages are learned ( $3^{\text {rd }}$ ed.). Oxford: OUP.

Raimes, A. (1985) Techniques in teaching writing. Oxford: OUP.

Rutherford, W., \& Sharwood-Smith, M. (1985). Consciousness - raising and universal grammar. Applied Linguistics, 6(3), 274 - 282.

Schmidt, R.W. (1990). The role of consciousness in second language learning. Applied Linguistics, 11(2), 129 - 159.

Selinker, L. (1972). Interlanguage. International Review of Applied Linguistics in Language Teaching, 10(3), 209-234.

Journal of the Scholarship of Teaching and Learning, Vol. 15, No. 3, June, 2015. 
O’Brien, J.

Sharwood Smith, M. (1981). Consciousness raising and the second language learner. Applied Linguistics, 2(2), 159 - 168.

Smith, D.A., \& Sutton, H.R. (1994). Powerful proofreading skills tips, techniques and tactics. Canada: Crisplearning.

Suzuki, R. (2007). Designing consciousness-raising tasks for and Economics English course. The Asian ESP Journal, 3(1), 22-36.

Swan, M. (1994). Design criteria for pedagogic and language rules. In M. Bygate, A. Tonkyn, \& A. Williams (Eds.), Grammar and the language teacher. Tokyo: Prentice Hall.

Umale, J. (2011). The effect of consciousness raising on errors in L2 question formation: An investigation of Omani students. Arab World English Journal, 2(4), 88-135.

Van Patten, B. (1990). Attending to form and content in the input. Studies in Second Language Acquisition 12, 287-301.

Vygotsky, L. (1978). Interaction between learning and development. Mind and Society. Cambridge, M.A.: Harvard University Press. 